\title{
Occurrence of Two Organisms in Cultures of the Type Strain of Spirillum lunatum: Proposal for Rejection of the Name Spirillum lunatum and Characterization of Oceanospirillum maris subsp. williamsae and an Unclassified Vibrioid Bacterium
}

\author{
Request for an Opinion
}

DANIEL M. LINN $\dagger$ AND NOEL R. KRIEG

Department of Biology, Virginia Polytechnic Institute and State University, Blacksburg, Virginia 24061

\begin{abstract}
The characteristics of ATCC 11337, the type strain of Spirillum lunatum Williams and Rittenberg 1957, do not fit the original description of the species. Cultures of this same strain held by the National Collection of Marine Bacteria under the number 54 appear to consist of two kinds of organisms: (i) relatively small, short, vibrio-shaped rods having single flagella, capable of growing in the presence or absence of seawater and of catabolizing certain sugars, incapable of forming coccoid bodies, and having a deoxyribonucleic acid base composition of 63 to $64 \mathrm{~mol} \%$ guanine plus cytosine (these organisms closely resemble those found in cultures of ATCC 11337), and (ii) relatively large organisms having a typical spirillum morphology with bipolar tufts of flagella, requiring seawater for growth, capable of forming coccoid bodies, incapable of catabolizing sugars, and having a deoxyribonucleic acid base composition of $45 \mathrm{~mol} \%$ guanine plus cytosine. The larger organisms have been placed in a new subspecies of Oceanospirillum maris, $O$. maris subsp. williamsae, the type strain of which is ATCC 29547. The smaller organisms do not appear to belong to either the genus Oceanospirillum or the genus Aquaspirillum, and their classification is not yet apparent. Because the name Spirillum lunatum has been a source of confusion, it is requested that the Judicial Commission place this name on the list of rejected names as a nomen confusum.
\end{abstract}

In their description of the marine bacterium Spirillum lunatum in 1957, Williams and Rittenberg (14) indicated a cell diameter of ca. $1.0 \mu \mathrm{m}$ and a requirement for at least $50 \%$ seawater for growth. Other characteristics included growth on the salts of various organic acids in synthetic media, the occurrence of bipolar, single flagella, and the presence of prominent intracellular granules. Moreover, coccoid bodies, or "microcysts," were predominant in older cultures (see also reference 13). Williams (12) emended the original description in 1960 upon finding, by electron microscopy, that bipolar tufts of flagella, rather than bipolar single flagella, were present. A strain was deposited with the American Type Culture Collection (ATCC) in 1957 under the number 11337 and was designated as the type strain (14). A culture of this same strain was also deposited with the National Collection of Marine Bacteria (NCMB) in 1958 under the number 54 (9).

† Present address: Department of Agronomy, University of Nebraska, Lincoln, NB 68583.
In 1972, Terasaki (10) reported that ATCC 11337 possessed a cell diameter of 0.3 to $0.5 \mu \mathrm{m}$, could grow in either the presence or absence of seawater, possessed unipolar or bipolar single flagella, failed to form coccoid bodies, and was devoid of metachromatic granules. Unlike other marine spirilla, the strain caused acidification of media in the presence of certain sugars. Hylemon et al. (2) confirmed these results and found the guanine plus cytosine $(\mathrm{G}+\mathrm{C})$ of the deoxyribonucleic acid (DNA) to be $63 \mathrm{~mol} \%$, distinctly different from the value of 42 to 48 $\mathrm{mol} \% \mathrm{G}+\mathrm{C}$ for all other marine spirilla.

Because of these differences from the original description of $S$. lunatum, the authenticity of cultures of the type strain and the taxonomic status of the species have been placed in doubt. The present study was initiated to clarify this problem.

\section{MATERIALS AND METHODS}

Bacterial strains. The strains of $S$. lunatum used throughout the study, with their respective sources, are as follows. 
Strain 1. Strain 1, ATCC 11337, was obtained on an agar slant directly from the ATCC in 1966. It was found to be pure despite exhaustive efforts to demonstrate a mixed culture. Additional cultures freeze-dried by the ATCC in 1957 and 1968 were also pure and were identical to the 1966 culture.

Strains $2 a$ and $2 b$. A culture of $S$. lunatum NCMB 54 was obtained in 1973 directly from the NCMB, where it had been preserved in 1972 by L-drying. This culture consisted of two types of cells, which we regard as belonging to two different strains: a smaller one, termed " $2 a$," and a larger one, termed " $2 b$." The smaller spirilla were morphologically similar to the cells of strain 1 and greatly predominated in the cultures. The larger spirilla were so few in number as to preclude isolation by streak-plate methods, and none of a variety of enrichment procedures proved to be successful. Isolation of strain $2 b$ was eventually achieved by the use of an antiserum, as described below. A second preserved culture of NCMB 54 also yielded cells identical to those of $2 \mathrm{a}$. Although attempts at recovering cells resembling those of $2 b$ from this culture were unsuccessful, microscopic examination of the freshly rehydrated contents of the ampoule revealed the presence of numerous coccoid bodies and free tufts of flagella-characteristics of $2 b$ cells. Moreover, examination of cultures of strain 54 by the NCMB indicated the occurrence of two different morphological types (J. M. Shewan, personal communication).

Strain 3. A culture derived from NCMB 54 was obtained in 1973 from Y. Terasaki, Biological Laboratory, Suzugamine Women's College, Hiroshima, Japan. Terasaki had been sent a liquid culture directly from the NCMB in 1968 and had transferred it and maintained a stock in his collection without selection of colonies. The culture received from Terasaki was found to be pure and to consist of cells that resembled 2b cells morphologically.

Characterization tests. Maintenance of stock cultures and determinations of colonial and cellular morphology, optimal temperatures, biochemical and nutritional characteristics, and DNA base compositions were performed by methods previously described (2).

Isolation procedure for strain $2 \mathrm{~b}$. To separate $2 \mathrm{~b}$ cells from the predominant $2 \mathrm{a}$ cells, antiserum prepared against $2 a$ cells was employed. The antigen for immunization of rabbits was a live saline suspension of $2 a$ cells adjusted to a turbidity of 400 Klett units (16-mm cuvettes, 420-nm filter). This suspension was mixed with an equal volume of Freund complete adjuvant, and $1.5 \mathrm{ml}$ was administered intramuscularly into each hind leg of the rabbit. After 4 weeks, blood was obtained by cardiac puncture; the serum portion was sterilized by filtration.

The isolation procedure for $2 \mathrm{~b}$ cells consisted of suspending the mixed culture in a 1:14 dilution of the antiserum. This suspension was incubated for $15 \mathrm{~min}$ at $30^{\circ} \mathrm{C}$. It was then centrifuged at low speed $(1,000$ $\times g$ ) to sediment the flocs of $2 \mathrm{a}$ cells. The supernatant was diluted in sterile synthetic seawater, and samples were added to molten $\left(45^{\circ} \mathrm{C}\right)$ peptone-succinate-salts (PSS) agar prepared with synthetic seawater (2). After incubation of the solidified plates at $30^{\circ} \mathrm{C}$ for $24 \mathrm{~h}$, two colony types were evident, one of which proved to consist of only $2 b$ cells.

\section{RESULTS}

The appearance of cells of strains $1,2 a$, and $2 b$ by phase-contrast microscopy is indicated in Fig. 1. Cells of strain 3 were identical in appearance to $2 \mathrm{~b}$ cells. Cells of strains 1 and $2 \mathrm{a}$, although helically curved, possessed less than one helical turn. Some cells were nearly straight rods. In contrast, cells of strains $2 \mathrm{~b}$ and 3 usually possessed one or more helical turns. The dimensions of the cells of the various strains are presented in Table 1.

Electron microscopy indicated that cells of strains 1 and 2a possessed predominantly a single polar flagellum; however, a few cells possessed either bipolar, single flagella or up to four flagella at one pole. In contrast, cells of strains $2 \mathrm{~b}$ and 3 exhibited predominantly bipolar tufts of flagella, averaging 7 to 10 flagella per tuft; a few cells possessed up to 16 flagella per tuft. Dark-field microscopy of motile $2 b$ cells and cells of strain 3 revealed the occurrence of helical flagellar fascicles at each pole; these were extended away from the cell poles regardless of the direction of swimming, as was described previously for Oceanospirillum maris (4). The flagella of cells of strains 1 and $2 a$ were not visible by dark-field microscopy.

Numerous coccoid bodies occurred only in cells of strains $2 \mathrm{~b}$ and 3 in cultures 1 to 4 weeks
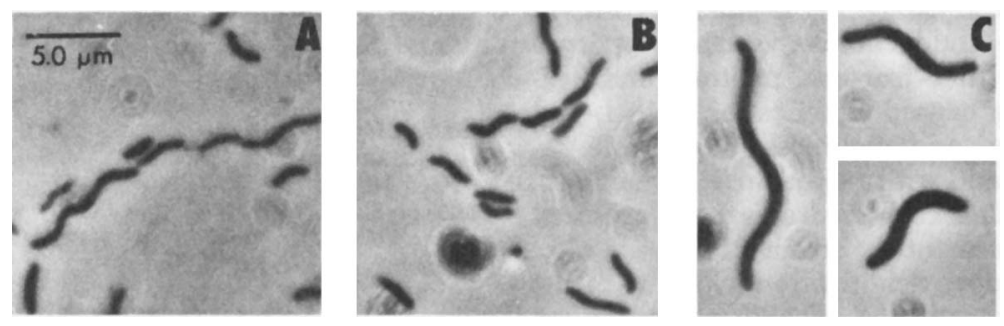

Fig. 1. Phase-contrast photomicrographs of cells of (A) strain 2a, (B) strain 1, and (C) strain 2b. The appearance of cells of strain 3 was nearly identical to that of cells of strain $2 b$. Organisms were cultured at $30^{\circ} \mathrm{C}$ for $24 \mathrm{~h}$ in PSS broth containing artificial seawater. 
TABLE 1. Dimensions of cells of strains $1,2 a, 2 b$ and 3

\begin{tabular}{|c|c|c|c|c|c|}
\hline \multirow[b]{2}{*}{ Strain } & \multicolumn{5}{|c|}{ Dimensions $^{\alpha}(\mu \mathrm{m})$} \\
\hline & Diam & $\begin{array}{l}\text { Wave- } \\
\text { length }\end{array}$ & $\begin{array}{l}\text { Helix } \\
\text { diam }\end{array}$ & Length & $\begin{array}{l}\text { Coc- } \\
\text { coid } \\
\text { body } \\
\text { diam }\end{array}$ \\
\hline 1 & $\begin{array}{c}0.5-0.9^{b} \\
(0.6)\end{array}$ & $\begin{array}{c}3.3-4.0 \\
(3.7)\end{array}$ & $\begin{array}{c}1.0-1.6 \\
(1.2)\end{array}$ & $\begin{array}{c}2.1-11.0 \\
(4.0)\end{array}$ & $-r$ \\
\hline $2 \mathrm{a}$ & $\begin{array}{c}0.3-0.7 \\
(0.5)\end{array}$ & $\begin{array}{c}1.9-2.9 \\
(2.3)\end{array}$ & $\begin{array}{c}0.6-1.3 \\
(0.8)\end{array}$ & $\begin{array}{c}2.2-23.0 \\
(4.6)\end{array}$ & - \\
\hline $2 b$ & $\begin{array}{c}0.7-1.0 \\
(0.8)\end{array}$ & $\begin{array}{c}4.4-6.0 \\
(5.5)\end{array}$ & $\begin{array}{c}1.5-2.0 \\
(1.7)\end{array}$ & $\begin{array}{c}4.4-20.5 \\
(9.0)\end{array}$ & $\begin{array}{c}1.5-2.9 \\
(2.2)\end{array}$ \\
\hline 3 & $\begin{array}{c}0.7-1.0 \\
(0.8)\end{array}$ & $\begin{array}{c}4.4-6.3 \\
(5.0)\end{array}$ & $\begin{array}{c}1.4-2.0 \\
(1.6)\end{array}$ & $\begin{array}{c}5.9-17.0 \\
(10.2)\end{array}$ & $\begin{array}{c}1.5-2.9 \\
(2.1)\end{array}$ \\
\hline
\end{tabular}

a Dimensions were determined from photomicrographs whose magnifications were determined by the use of a stage micrometer.

'The range is given, followed by the mean value in paren. theses.

c Strain 1 and $2 a$ cells do not form coccoid bodies.

old. The diameters of the coccoid bodies are indicated in Table 1.

The temperature for optimum growth of all strains was $30^{\circ} \mathrm{C}$. Moderate growth was noted at 15,25 , and $37^{\circ} \mathrm{C}$ for strains 1 and $2 \mathrm{a}$; strains $2 b$ and 3 differed in that no growth occurred at $37^{\circ} \mathrm{C}$. None of the strains grew at $45^{\circ} \mathrm{C}$.

Luxuriant, turbid growth was obtained with all strains in PSS broth under aerobic conditions in $24 \mathrm{~h}$. No growth except for that of strains 1 and 2a occurred under anaerobic conditions; these strains could grow anaerobically if $0.1 \%$ $\mathrm{KNO}_{3}$ was provided as a terminal electron acceptor, and gas formation was evident under this condition.

On PSS agar, strains 1 and $2 a$ formed circular, convex, opaque, white- to buff-colored colonies that were 0.5 to $1.0 \mathrm{~mm}$ in diameter within 48 to $72 \mathrm{~h}$. Strains $2 \mathrm{~b}$ and 3 formed similar buffcolored colonies that were pinpoint to $0.5 \mathrm{~mm}$ in diameter within $72 \mathrm{~h}$.

With regard to carbohydrate catabolism, strain 1 caused acidification of the medium when cultured with D-galactose, D-glucose, D-mannose, $D$-xylose, and melibiose; variable responses were found with D-fructose, maltose, and dextrin. Strain 2a caused acidification with D-glucose, D-xylose, and melibiose; a variable response was found with D-galactose, D-mannose, and salicin. The carbohydrates were oxidized rather than fermented. Strains $2 b$ and 3 were unable to produce acidification with any of the 31 carbohydrates tested, including L-arabinose, D-mannitol, D-raffinose, L-rhamnose, D-ribose, D-trehalose, adonitol, amygdalin, cellobiose, cellulose, dulcitol, erythritol, glycerol, glycogen, in- ulin, inositol, lactose, melizitose, pectin, sorbitol, sorbose, and sucrose.

Physiological characteristics of the organisms are presented in Table 2. With regard to catalase activity, it was noted that, although all strains were positive, strains $2 b$ and 3 gave a delayed response; visible oxygen production occurred only 15 to $20 \mathrm{~min}$ after addition of the hydrogen peroxide. Differences between strains 1 and $2 a$ versus $2 b$ and 3 were also evident from several other tests ('Table 2).

All strains were capable of growth in $\mathrm{NaCl}$ concentrations as high as $9.75 \%$, and strains 1 and $2 a$ could grow weakly even with $12.75 \%$ $\mathrm{NaCl}$. Strains 1 and $2 a$ also grew well in PSS broth prepared with either distilled water or with synthetic seawater, in contrast to strains $2 b$ and 3 , both of which were incapable of growing with less than 40 to $50 \%$ seawater.

Table 3 lists the growth responses of strains 1 and $2 a$ when tested with 47 sole carbon sources. The strains used the same spectrum of compounds with the exception of fumarate, acetate, $n$-propanol, and D-gluconate. Nearly all of the tricarboxylic acid cycle intermediates and re-

TABLE 2. Physiological characteristics of strains 1 , $2 a, 2 b$, and 3

\begin{tabular}{|c|c|c|c|c|}
\hline \multirow{2}{*}{ Test } & \multicolumn{4}{|c|}{ Strain } \\
\hline & 1 & $2 a$ & $2 b$ & 3 \\
\hline Oxidase & $t^{a}$ & + & + & + \\
\hline$\ldots \ldots \ldots \ldots$ & + & + & $\mathbf{W}$ & $\mathbf{W}$ \\
\hline Phosphatase . . . . . . . . . . & + & + & - & - \\
\hline $\mathrm{H}_{2} \mathrm{~S}$ from $0.2 \%$ cysteine & + & + & + & + \\
\hline Indole production $\ldots \ldots \ldots \ldots$ & - & - & - & - \\
\hline $\begin{array}{l}\text { Casein, esculin, hippurate, and } \\
\text { starch hydrolysis } \ldots \ldots \ldots \ldots\end{array}$ & - & - & - & - \\
\hline Urease $\ldots \ldots \ldots \ldots$ & + & + & - & - \\
\hline Gelatin liquefaction & - & - & - & - \\
\hline Nitrate reduced to nitrite & - & - & - & - \\
\hline Denitrification $\ldots \ldots \ldots$ & + & + & - & - \\
\hline Anaerobic growth with nitrate & + & + & - & - \\
\hline Selenite reduction $\ldots \ldots \ldots$ & $x$ & $x$ & - & - \\
\hline $\begin{array}{l}\text { Deoxyribonuclease and ribonucle- } \\
\text { ase activity } \ldots \ldots \ldots \ldots \ldots\end{array}$ & + & + & + & + \\
\hline $\begin{array}{l}\text { Acid reaction from carbohydrates } \\
\text { Growth in presence of: }\end{array}$ & + & + & - & - \\
\hline 1\% bile (oxgall) & + & + & + & + \\
\hline $1 \%$ glycine & + & + & - & - \\
\hline $9.75 \% \mathrm{NaCl}$ & + & + & + & + \\
\hline $\begin{array}{l}12.75 \% \text { Nacl } \ldots \ldots \ldots \\
\text { Water-8oluble fluorescent }\end{array}$ & $\mathbf{W}$ & $\mathbf{W}$ & - & - \\
\hline $\begin{array}{l}\text { pigment } \\
0.2 \% \text { aromatic amino acids: }\end{array}$ & + & + & + & + \\
\hline Phenylalanine $\ldots \ldots \ldots \ldots \ldots$ & - & - & - & - \\
\hline Tryptophan & $\mathbf{B}$ & $\mathbf{B}$ & B & $\mathbf{B}$ \\
\hline Tyrosine & $\mathbf{B}$ & $\mathbf{B}$ & DB & $\mathrm{DB}$ \\
\hline $\begin{array}{l}\text { Intracellular poly- } \boldsymbol{\beta} \text {-hydroxybuty- } \\
\text { rate }^{\mathbf{b}} \ldots \ldots \ldots \ldots \ldots\end{array}$ & - & - & + & + \\
\hline
\end{tabular}

a Symbols; + , positive response; - , negative response; $W$, weak response; $x$, delayed response; $B$, brown water-soluble pigment; DB, dark-brown water-soluble pigment.

'Determined by the method of Law and Slepecky (8). 
lated compounds, as well as a moderate number of amino acids, supported growth. Except for D-gluconate, which allowed strain 1 to grow slightly, carbohydrates appeared not to support growth. However, a 1971 nutritional study in our laboratory by P. B. Hylemon (Ph.D. thesis, Virginia Polytechnic Institute and State University, Blacksburg) indicated a slight growth response of strain 1 with glucose, mannitol, and glycerol, as well as with gluconate. Terasaki (10), using a different method, also found utilization of glucose by strain 1 . Consequently, it would appear that, as with acid production from carbohydrates, variable responses may occur when testing carbohydrates as sole carbon sources. In contrast to strains 1 and $2 a$, strains $2 b$ and 3 failed to grow with any of the sole carbon sources provided.

Strains 1 and $2 a$ also exhibited versatility in using a large number of sole nitrogen sources when succinate and malate were provided as carbon sources. The nitrogen sources used included urea, nitrate, ammonium sulfate, and all amino acids except L-histidine, L-hydroxyproline, and L-lysine. In contrast, strains $2 b$ and 3 failed to grow with any of the sole nitrogen sources provided. Because neither sole carbon nor sole nitrogen sources were used by these latter strains, it seems likely that they are auxotrophs, as has been reported for certain other spirilla (viz. Aquaspirillum gracile [4] and Aquaspirillum aquaticum [6]).

The DNA melting points (thermal denaturation) for the organisms were: $95.3^{\circ} \mathrm{C}$ for strain $1 ; 95.7^{\circ} \mathrm{C}$ for strain $2 \mathrm{a} ; 87.8^{\circ} \mathrm{C}$ for strain $2 \mathrm{~b}$; and $88.0^{\circ} \mathrm{C}$ for strain 3 . These values correspond to $\mathrm{G}+\mathrm{C}$ values of $63,64,45$, and $45 \mathrm{~mol} \%$, respectively.

\section{DISCUSSION}

The isolation of two distinctly different helically curved organisms from a culture of NCMB 54 preserved in 1972, together with the demonstration that one of them (2a cells) is not a typical marine spirillum but is very similar to organisms comprising ATCC 11337, suggests that perhaps the type strain of $S$. lunatum is represented by strain $2 b$ or strain 3 and that contamination of cultures of the type strain with cells of strain 1 or $2 a$ occurred at some point in the past. Assuming this for the moment, it would not seem likely that the contamination occurred after deposition of the type strain, because deposition was made separately at the ATCC and the NCMB and also because it would be unlikely that the same (or nearly so) unusual contaminant would have appeared in both cases. It is much more likely that the cultures of the type
TABLE 3. Sole carbon sources for strains 1 and $2 a$

\begin{tabular}{|c|c|c|}
\hline \multirow{2}{*}{ Compound } & \multicolumn{2}{|c|}{ Utilization $^{a}$ by: } \\
\hline & Strain 1 & $2 \mathbf{a}$ \\
\hline$\ldots \ldots \ldots \ldots \ldots$ & +++ & +++ \\
\hline Aconitate $\ldots \ldots \ldots \ldots \ldots$ & ++ & ++ \\
\hline Isocitrate $\ldots \ldots \ldots \ldots \ldots$ & ++ & ++ \\
\hline$\alpha$-Ketoglutarate $\ldots \ldots \ldots \ldots$ & + & + \\
\hline Succinate $\ldots \ldots \ldots \ldots \ldots$ & + & + \\
\hline Fumarate & + & - \\
\hline DL-Malate $\ldots \ldots \ldots$ & +++ & +++ \\
\hline Oraloacetate $\ldots \ldots \ldots \ldots$ & + & $+t$ \\
\hline Pyruvate $\ldots \ldots \ldots \ldots$ & +++ & +++ \\
\hline L-Lactate $\ldots \ldots \ldots \ldots \ldots \ldots$ & $++t$ & $+t$ \\
\hline Malonate $\ldots \ldots \ldots \ldots \ldots$ & ++ & ++ \\
\hline Acetate $\ldots \ldots \ldots \ldots$ & ++ & - \\
\hline Propionate & - & - \\
\hline Caproate $\ldots \ldots \ldots \ldots \ldots$ & - & - \\
\hline$\beta$-Hydroxybutyrate $\ldots \ldots \ldots$ & - & - \\
\hline Ethanol $\ldots \ldots \ldots \ldots \ldots$ & - & - \\
\hline$n$-Propanol $\ldots \ldots \ldots \ldots \ldots$ & ++ & - \\
\hline$n$-Butanol $\ldots \ldots \ldots$ & - & - \\
\hline$\ldots \ldots \ldots \ldots$ & - & - \\
\hline D-Glucose $\ldots \ldots \ldots \ldots$ & - & - \\
\hline D-Gluconate $\ldots \ldots \ldots \ldots$ & + & - \\
\hline D-Mannitol $\ldots \ldots \ldots \ldots$ & - & - \\
\hline D-Fructose $\ldots \ldots \ldots$ & - & - \\
\hline D-Galactose $\ldots \ldots \ldots \ldots$ & - & - \\
\hline D-Mannose $\ldots \ldots \ldots \ldots$ & - & - \\
\hline L-Histidine $\ldots \ldots \ldots \ldots$ & - & - \\
\hline L-Tyrosine $\ldots \ldots \ldots \ldots$ & ++ & ++ \\
\hline L-Phenylalanine $\ldots \ldots \ldots \ldots$ & - & - \\
\hline L-Alanine $\ldots \ldots \ldots \ldots$ & ++ & +++ \\
\hline L-Glutamate $\ldots \ldots \ldots \ldots \ldots$ & + & + \\
\hline L-Aspartate $\ldots \ldots \ldots \ldots$ & - & - \\
\hline L-Glutamine $\ldots \ldots \ldots \ldots$ & + & ++ \\
\hline L-Asparagine $\ldots \ldots \ldots \ldots$ & ++ & +++ \\
\hline L-Proline & + & + \\
\hline L-Hydroxyproline $\ldots \ldots \ldots$ & - & - \\
\hline L-Ornithine $\ldots \ldots \ldots \ldots$ & - & - \\
\hline L-Citrulline $\ldots \ldots \ldots \ldots$ & - & - \\
\hline L-Arginine $\ldots \ldots \ldots \ldots$ & - & - \\
\hline L-Lysine $\ldots \ldots \ldots$ & - & - \\
\hline L-Methionine & - & - \\
\hline L-Serine $\ldots \ldots \ldots \ldots \ldots$ & - & - \\
\hline L-Cysteine $\ldots \ldots \ldots \ldots \ldots$ & - & - \\
\hline Glycine $\ldots \ldots \ldots \ldots$ & + & + \\
\hline L-Leucine & - & - \\
\hline L-Isoleucine & - & - \\
\hline L-Valine ... & - & - \\
\hline L-Threonine & - & - \\
\hline
\end{tabular}

${ }^{a}$ Growth responses were measured as described previously (2). Symbols:,$+++>35$ Klett units of turbidity;,++ 20 to 35 Klett units;,+ 10 to 20 Klett units;,$-<10$ Klett units.

strain contained a contaminant before deposition in either collection. According to this hypothesis, the small contaminant organism became predominant in the ATCC cultures and the large, marine organism soon died out, whereas in the NCMB cultures the large marine 
organism still remains in very low numbers. In apparent contradiction to this hypothesis, the culture of strain 3 received from Terasaki was derived from an NCMB liquid culture of strain 54 sent in 1968 which seemed to contain only the large marine organism (Terasaki, personal communication). It is possible, however, that, if very low numbers of the contaminant had been present in NCMB stocks, the particular culture sent to Terasaki might not have contained the contaminant, or, if it was present initially, it might have been unable to compete effectively during shipment or during subsequent cultivation under the conditions employed. Unfortunately, cultures of strain 54 preserved before 1971 are no longer available from the NCMB. It is clear, however, that cultures preserved in 1972 do contain, in addition to a few large spirilla, many smaller organisms that are similar to those comprising cultures of ATCC 11337 preserved as early as 1957 . The difference in survival of the large spirilla at the two collections might possibly be attributable to differences in preservation methods or in choice of recovery media. The ATCC employed freeze-drying of $S$. lunatum cultures and used marine agar 2216 (Difco) for recovery, whereas the NCMB employed L-drying and used a liquid medium devised by Williams and Rittenberg (14) for recovery.

As indicated above, it is possible that strains $2 b$ and 3 are true representatives of the type strain of $S$. lunatum. The requirement for seawater, the formation of coccoid bodies, the occurrence of bipolar tufts of flagella, the presence of prominent intracellular granules, and a relatively large cell diameter are all consistent with the original description (14) or its emendation (12). Nevertheless, certain inconsistencies exist that might possibly be explained on the basis of a mixed culture, and we submit that it would be difficult to be certain that strains $2 \mathrm{~b}$ and 3 in fact represent the type strain of $S$. lunatum. For example, whereas strains $2 b$ and 3 are unable to use any of a large number of sole carbon sources, $S$. lunatum was described as being able to grow well on the salts of pyruvic, succinic, fumaric, malic, and lactic acids, and also on glucose and fructose, in synthetic media. S. lunatum was also described as being able to use ammonium salts, nitrate, urea, and asparagine as sole nitrogen sources in synthetic media, whereas strains $2 b$ and 3 are unable to use any of a large number of sole nitrogen sources, are devoid of urease activity, and are unable to reduce nitrate even to nitrite. Furthermore, phase-contrast photomicrographs of $S$. lunatum published in 1956 (see Fig. 1 of reference 13) and 1957 (see Fig. 6 of reference 14) indicate a number of cells having diameters of ca. $0.5 \mu \mathrm{m}$; it is not certain, however, that the photomicrographs are of the type strain.

Classification of strains $2 b$ and 3. Because of the occurrence of bipolar flagellar tufts, the ability to grow in $9.75 \% \mathrm{NaCl}$, the requirement for seawater, the inability to ferment or oxidize carbohydrates, the occurrence of intracellular poly- $\beta$-hydroxybutyrate granules, and a DNA base composition of $45 \mathrm{~mol} \% \mathrm{G}+\mathrm{C}$, we consider strains $2 b$ and 3 to be typical members of the genus Oceanospirillum (2).

A comparison of the characteristics of strains $2 \mathrm{~b}$ and 3 with those of the various species of Oceanospirillum indicates considerable similarity to members of the species Oceanospirillum maris (2). The similarities include cellular dimensions, DNA base composition, lack of phosphatase activity, sulfide formation from cysteine, growth in $1 \%$ bile, pigment production from aromatic amino acids, and coccoid-body formation. One of the most striking morphological similarities is the configuration of the flagellar tufts, previously described for $O$. maris (4). Of all of the species of Oceanospirillum described by Hylemon et al. (2), only $O$. maris exhibits this configuration.

Dissimilarities between $O$. maris and strains 2b and 3 include the following: (i) the catalase reaction for $O$. maris is strong, whereas it is very weak for strains $2 b$ and 3 ; (ii) strains $2 b$ and 3 possess both deoxyribonuclease and ribonuclease activity, whereas $O$. maris does not; (iii) $O$. maris was able to grow in $1 \%$ glycine, in contrast to strains $2 b$ and 3 ; and (iv) although $O$. maris could use a limited number of compounds as sole carbon sources, strains $2 \mathrm{~b}$ and 3 could use none of the compounds tested. Moreover, $O$. maris was quite versatile with respect to sole nitrogen sources, whereas strains $2 \mathrm{~b}$ and 3 could use none of a large variety provided. Strains $2 b$ and 3 cells appear to be auxotrophs, but what specific nutritional requirement they have is not yet known.

In view of the numerous similarities between members of $O$. maris and strains $2 \mathrm{~b}$ and 3 , we consider the dissimilarities cited above to have relatively minor importance. For example, the failure of strains $2 b$ and 3 to utilize any sole carbon or nitrogen source might possibly be attributable to a mutation in a gene involved in the biosynthesis of a vitamin. Because no exogenous vitamins or other special growth factors were included in the defined medium employed to test sole carbon and nitrogen sources, an auxotrophic mutant would not have been able to grow. With regard to the catalase reaction, the differences appear to be quantitative rather than qualitative. It should be noted that the 
catalase reaction for the species Oceanospirillum linum has been reported to range from weak to strong (2). Consequently, in our opinion, the few dissimilarities between members of $O$. maris and strains $2 b$ and 3 represent differences at the subspecies rather than at the species level. We therefore believe that strains $2 \mathrm{~b}$ and 3 belong to a new subspecies of $O$. maris Hylemon et al. (2), for which we propose the name Oceanospirillum maris subsp. williamsae.

Oceanospirillum maris subsp. williamsae subsp. nov. (wil'liams.ae. M.L. gen. noun williamsae of Williams, named for Marion Williams).

The characteristics of the subspecies are described previously for the species (2), with the following exceptions: (i) the catalase reaction is weak; (ii) deoxyribonuclease and ribonuclease activities are present; (iii) growth does not occur in the presence of $1 \%$ glycine; and (iv) sole carbon or nitrogen sources are not used, and the subspecies appears to have auxotrophic requirements. The type strain is ATCC 29547 (2b cells).

According to the rules of nomenclature for bacteria, when a species is divided into one or more subspecies, the type subspecies, the name of which retains the specific epithet of the species as the subspecific epithet, is automatically created, and the author(s) of the species name is (are) to be cited as the author of the automatically created subspecific name. Thus, the name of the type subspecies is $O$. maris subsp. maris Hylemon et al. The type strain of the type subspecies is the same as that for the species, i.e., ATCC 27509 (2).

Classification of strains 1 and 2a. Two of the most compelling reasons for excluding strains 1 and $2 \mathrm{a}$ from the genus Oceanospirillum concern not only their ability to grow in either the presence of absence of seawater but also their high mole percent $\mathrm{G}+\mathrm{C}$. The genus Oceanospirillum has a G+C range of 42 to $48 \mathrm{~mol} \%$, whereas strains 1 and 2a have a value of 63 to $64 \mathrm{~mol} \%$. This would be in the range for the genus Aquaspirillum; however, placement of these organisms in this genus is hampered by the ability of the organisms to grow in $\mathrm{NaCl}$ concentrations greater than $3 \%$, a characteristic not found in any of the present members of Aquaspirillum. A number of other characteristics occurring in strains 1 and $2 a$ are also atypical of Aquaspirillum, although some species of the genus may possess one or more of them. These characteristics are as follows: (i) a vibrio shape is not typical of spirilla, although Aquaspirillum delicatum does possess such a shape (2); (ii) predominantly single flagella occur only in $A$. delicatum (2); (iii) an ability to denitrify and to grow anaerobically with nitrate occurs only in A. itersonii $(2,10), A$. dispar (5), and Spirillum psychrophilum (11); (iv) the ability to catabolize carbohydrates is limited to $A$. itersonii, $A$. peregrinum, and $A$. gracile $(2,10) ;(v)$ growth in the presence of $1 \%$ glycine occurs only with $A$. dispar and A. aquaticum (2); (vi) formation of brown water-soluble pigments from tyrosine or tryptophan is limited to $A$. itersonii and $A$. bengal $(2,7)$; (vii) lack of intracellular poly- $\beta$ hydroxybutyrate is found only with $A$. gracile (2). None of these characteristics alone would exclude strains 1 and $2 \mathrm{a}$ from the genus Aquaspirillum, but taken together they carry considerable weight. Moreover, in comparing ATCC strain 11337 to other spirilla by numerical taxonomy, Terasaki (10) found it to have less than $70 \%$ similarity to any other strain studied. Similarly, Carney et al. (1) also observed that the relationship of ATCC strain 11337 to other spirilla was lower than for any other spirillum tested.

In view of the atypical nature of strains 1 and $2 a$, we believe that they should not be included at the present time in either the genus Aquaspi. rillum or the genus Oceanospirillum. Into what genus they should be placed is not yet apparent. It is possible that they may represent a new genus. However, their classification should await further information and also the isolation of additional strains.

Status of the name S. lunatum. Because it is likely that the type strain of $S$. lunatum consisted of two kinds of organisms prior to its deposition in the ATCC and the NCMB, thereby causing the name $S$. lunatum to be a source of confusion, it is requested that the Judicial Commission issue an opinion placing this name on the list of rejected names as a name causing confusion (nomen confusum). The description of $S$. lunatum given in the 8th edition of Bergey's Manual of Determinative Bacteriology (3) was based on ATCC 11337 and should be omitted from subsequent editions of the Manual.

\section{REPRINT REQUESTS}

Address reprint requests to: Dr. Noel R. Krieg, Department of Biology, Virginia Polytechnic Institute and State University, Blacksburg, VA 24061.

\section{LTERATURE CITED}

1. Carney, J. F., I. Wan, T. E. Lovelace, and R. R. Colwell. 1975. Numerical taxonomy study of Vibrio and Spirillum spp. Int. J. Syst. Bacteriol. 25:38-46.

2. Hylemon, P. B., J. S. Wells, Jr., N. R. Krieg, and H. W. Jannasch. 1973. The genus Spirillum: a taxonomic study. Int. J. Syst. Bacteriol. 23:340-380.

3. Krieg, N. R. 1974. Genus I. Spirillum Ehrenberg 1832, 38, p. 196-206. In R. E. Buchanan and N. E. Gibbons (ed.), Bergey's manual of determinative bacteriology, 8th ed. The Williams and Wilkins Co., Baltimore. 
4. Krieg, N. R. 1976. Biology of the chemoheterotrophic spirilla. Bacteriol. Rev. 40:55-115.

5. Krieg, N. R., and P. B. Hylemon. 1976. The taxonomy of the chemoheterotrophic spirilla. Annu. Rev. Microbiol. 30:303-325.

6. Kropinski, A. M. 1975. A chemically-defined medium for Aquaspirillum aquaticum ATCC 11330. Can. J Microbiol. 21:1886-1889.

7. Kumar, R., A. K. Banerjee, J. H. Bowdre, L. J. MeElroy, and N. R. Krieg. 1974. Isolation, characterization, and taxonomy of Aquaspirillum bengal sp. nov. Int. J. Syst. Bacteriol. 24:453-458.

8. Law, J. H., and R. A. Slepecky. 1961. Assay of poly- $\beta$ hydroxybutyric acid. J. Bacteriol. 82:33-46.

9. Sneath, P. H. A., and V. B. D. Skerman. 1966. A list of type and reference strains of bacteria. Int. Bull. Bacteriol. Nomencl. Taxon. 16:1-133.
10. Terasaki, Y. 1972. Studies on the genus Spirillum Ehrenberg. I. Morphological, physiological, and biochemical characteristics of water spirilla. Bull. Suzugamine Women's Coll. Nat. Sci. 16:1-146.

11. Terasaki, Y. 1973. Studies on the genus Spirillum Ehrenberg. II. Comments on type and reference strains of Spirillum and descriptions of new species and subspecies. Bull. Suzugamine Women's Coll. Nat. Sci. 17:1-71

12. Williams, M. A. 1960. Flagellation in six species of Spirillum-a correction. Int. Bull. Bacteriol. Nomencl. Taxon. 10:193-196.

13. Williams, M. A., and S. C. Rittenberg. 1956. Microcyst formation and germination in Spirillum lunatum. J. Gen. Microbiol. 15:205-209.

14. Williams, M. A., and S. C. Rittenberg. 1957. A taxonomic study of the genus Spirillum Ehrenberg. Int. Bull. Bacteriol. Nomencl. Taxon. 7:49-111.

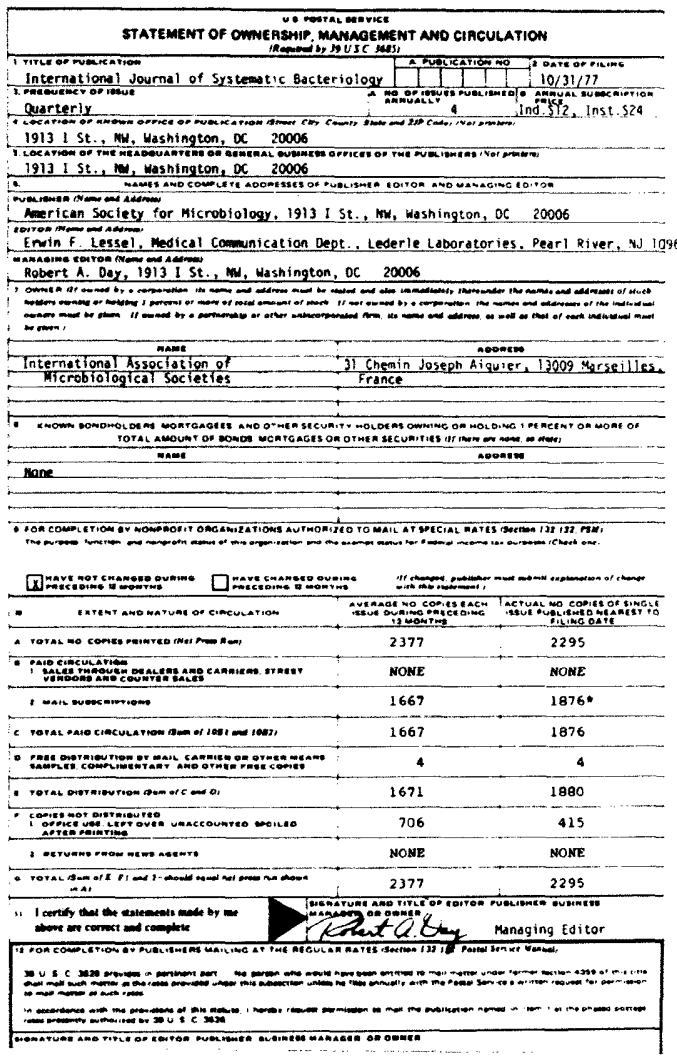

